\title{
Characterisation of adenoid cystic carcinoma of the breast by immunohistology
}

\author{
W DÜE, H HERBST, V LOY, H STEIN \\ From the Institute of Pathology, Klinikum Steglitz, Free University of Berlin, West Germany
}

SUMMARY An adenoid cystic carcinoma of the breast in a 78 year old woman was analysed immunohistologically for the production of type IV collagen, the expression of vimentin, epithelial membrane antigen (EMA) and steroid receptors, and the proliferative activity of the tumour cells. The data were compared with those obtained in eight adenoid cystic carcinomas of salivary glands and in ductal carcinomas of the breast with a cribriform growth pattern. The patients' ages were as follows: $45-80$ years (mean 63.2) for the salivary gland carcinomas; 37-69 years (mean 50.6) for the ductal breast carcinomas. In contrast to the cribriform spaces of ductal carcinomas, the pseudocysts in adenoid cystic carcinomas were lined by type IV collagen. The opposite pattern was observed for EMA. Like the myoepithelium of normal breast, the myoepithelium-like cells of adenoid cystic carcinoma stained positive for vimentin while the ductular epithelium-like ones did not. All adenoid cystic carcinomas, including that of the breast, were negative for the oestrogen and progesterone receptors, unlike the ductal carcinomas. Proliferative activity of the adenoid cystic carcinoma of the breast was relatively low.

These data broaden the range of antibodies suitable for differential diagnosis of both tumour types. They may explain the differences in prognosis, and they explain why hormonal treatment or radiotherapy of adenoid cystic carcinoma of the breast are often ineffectual.

While common in salivary glands,' adenoid cystic carcinomas of the breast are rare. ${ }^{2}$ They are composed of duct lining and myoepithelium-like cells with a dimorphic differentiation into ductular and pseudocystic spaces. ${ }^{12}$ Because pseudocystic areas can be more numerous than the ductular ones, ${ }^{23}$ adenoid cystic carcinoma of the breast can easily be confused with ductal carcinoma with a cribriform growth pattern. This differential diagnosis, however, is of some interest, because the first of these tumours is associated with a better prognosis. ${ }^{46}$ While both can be distinguished by their distribution of laminin and fibronectin, ${ }^{7}$ this seems not to be true for type III collagen. ${ }^{8}$

In the present study the production of type IV collagen, as a further component of the basement membrane, and the expression of vimentin were immunohistologically examined in adenoid cystic carcinomas of salivary glands and of the breast, and were compared with those of ductal breast carcinomas with a cribriform growth pattern. From results of previous immunohistological $^{78}$ and ultrastructural studies ${ }^{37-16}$

Accepted for publication 12 January 1989 of basement membrane distribution, it was thought that both tumour types should also differ in their pattern of epithelial membrane antigen (EMA) distribution, the determination of which could provide additional information for differential diagnosis. Because this differential diagnosis may be relevant not only for prognosis but also for treatment, the expression of oestrogen and progesterone receptors was also determined immunohistologically. As prognosis may be influenced and explained by differences in the proliferative activity of tumours ${ }^{4}$ the growth fraction was examined in both tumour types using the monoclonal antibody $\mathrm{Ki}-67$, which detects an antigen expressed in all stages of the cell cycle except $\mathrm{G}_{0} \cdot{ }^{17}$

\section{Material and methods}

The adenoid cystic carcinoma of the breast was obtained from a 78 year old woman. The tumour had first been diagnosed five years previously through the resection of a $50 \times 30 \times 30 \mathrm{~mm}$ mass from between the upper quadrants. Histologically, the carcinoma showed an infiltration of the corium and was well circumscribed and surrounded by fibrotic breast tis- 
sue. The patient was then admitted for follow up without further treatment. In May 1988 a newly developed nodule with a maximal diameter of $9 \mathrm{~mm}$, located beside the areola, was resected from the right breast and again diagnosed as adenoid cystic carcinoma with infiltration of the corium. Simple mastectomy was carried out and a biopsy specimen showed no remaining tumour, but fibrosis and mild chronic inflammation of the breast. According to the grading system of Szanto et $a l^{18}$ which was developed for adenoid cystic carcinomas of salivary glands, the tumour was judged to be grade II. No secondary tumour was present.

For comparison, eight adenoid cystic carcinomas of major and minor salivary glands were randomly selected from the files of our laboratory. According to Szanto et al ${ }^{18}$ three had to be classified as grade I, one as grade II, and four as grade III. Seven ductal carcinomas of the breast were also selected, which contained areas of cribriform growth and which had to be classified as grade II, according to Bloom and Richardson. ${ }^{19}$ Six of them were invasive; the seventh was exclusively intraductal. Cryostat sections of all breast tumours were also available.

Immunohistological staining was done using the alkaline phosphatase-antialkaline phosphatase staining procedure, ${ }^{20}$ as modified by Stein et al. ${ }^{21}$ The sections were examined using two monoclonal antibodies directed against different epitopes of type IV collagen- $\mathrm{NCl},{ }^{22}$ directed against the carboxyterminal cross-linking domain; CIV $22,{ }^{23}$ kindly donated from Dr Odermatt, Zurich, Switzerland, directed against a conformational epitope on type IV collagen. The slides were also stained for vimentin (V9 Dako), ${ }^{24}$ EMA (E29 Dako), ${ }^{25}$ as well as against the oestrogen receptor (ER-ICA, Abbott) ${ }^{26}$ and the progesterone receptor (mPRI, TransBio). ${ }^{27}$ The antibody $\mathrm{Ki}-67$, which detects a proliferation-associated antigen, ${ }^{17}$ like $\mathrm{NCl}$ is only suitable for cryostat sections. For sections fixed in formaldehyde and embedded in paraffin wax, a pre-treatment was necessary ${ }^{28}$ for valid detection of the oestrogen receptor.

\section{Results}

\section{ADENOID CYSTIC CARCINOMA OF THE BREAST}

The adenoid cystic carcinoma of the breast showed the typical differentiation into myoepthelium-like cells and cells resembling ductular epithelium, with a formation of small ductules and predominating areas

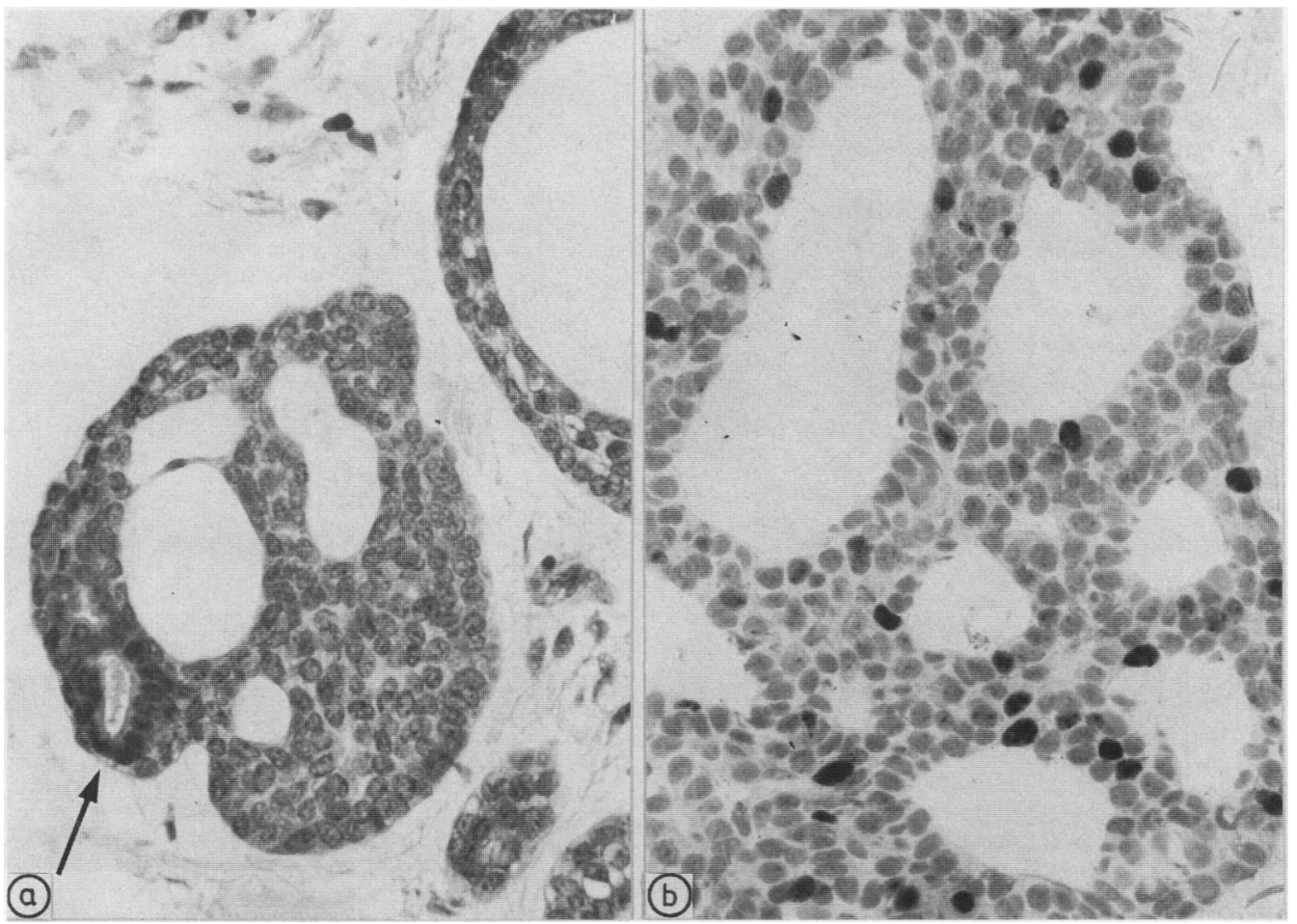

Fig 1 (a) Adenoid cystic carcinoma of the breast composed of pseudocystic and ductular spaces (arrow) Oestrogen receptor is not detected in both tumour components. (ER-ICA.)

(b) The growth fraction, as indicated by the nuclear reaction product, is about $10 \%$. (Ki-67.) 
of pseudocystic appearance (fig la). Nevertheless, the ductules were easily detectable by routine hematoxylin and eosin staining. In 1985 and 1988, pre-existing ductules were interspersed, partly with mild epitheliosis. Solid areas were present, but they comprised less than $10 \%$ of the tumour mass.

Both antibodies against type IV collagen showed a distinct laminar staining pattern which surrounded both the outer border of all tumour growth and the inner "surface" of pseudocystic spaces. The inner surface of the ductules, which by conventional light microscopy seemed to form true spaces, showed no staining for type IV collagen (fig 2a). The reaction for EMA showed the opposite pattern. The pseudocystic spaces and their lining epithelium did not stain while the cells lining true ductules showed a discrete reaction that was accentuated at the luminal cell border. The content of the true lumina also stained slightly (fig 3a). A dot-like reactivity was observed in a minority of those cells designated as myoepithelium-like. The oestrogen and progesterone receptors were not shown in any of the tumour cells while there was a distinct reaction within the interspersed pre-existing ductular epithelium, which served as an internal control. Vimentin did not stain the ductular epithelium within the tumour. In contrast, nearly all myoepthelium-like tumour cells were intracytoplasmatically stained for vimentin, resulting in a cord-like boundary of the pseudocystic spaces (fig 4a). All these results were identical for cryostat and paraffin wax sections. The immunohistologically determined growth fraction was about $10 \%$ (fig lb); only myoepithelium-like cells were identified as proliferating.

\section{ADENOID CYSTIC CARCINOMAS OF SALIVARY GLANDS}

The antigenic pattern was exactly the same for all tumours as that reported for the adenoid cystic carcinoma of the breast. Even those tumour cell groups at the margin, which were clearly infiltrating skeletal muscles, were completely surrounded by type IV collagen, and this was true for all the tumour manifestations forming the outer margin of the whole tumour.

DUCTAL CARCINOMA OF THE BREAST

Both type IV collagen antibodies showed that basal

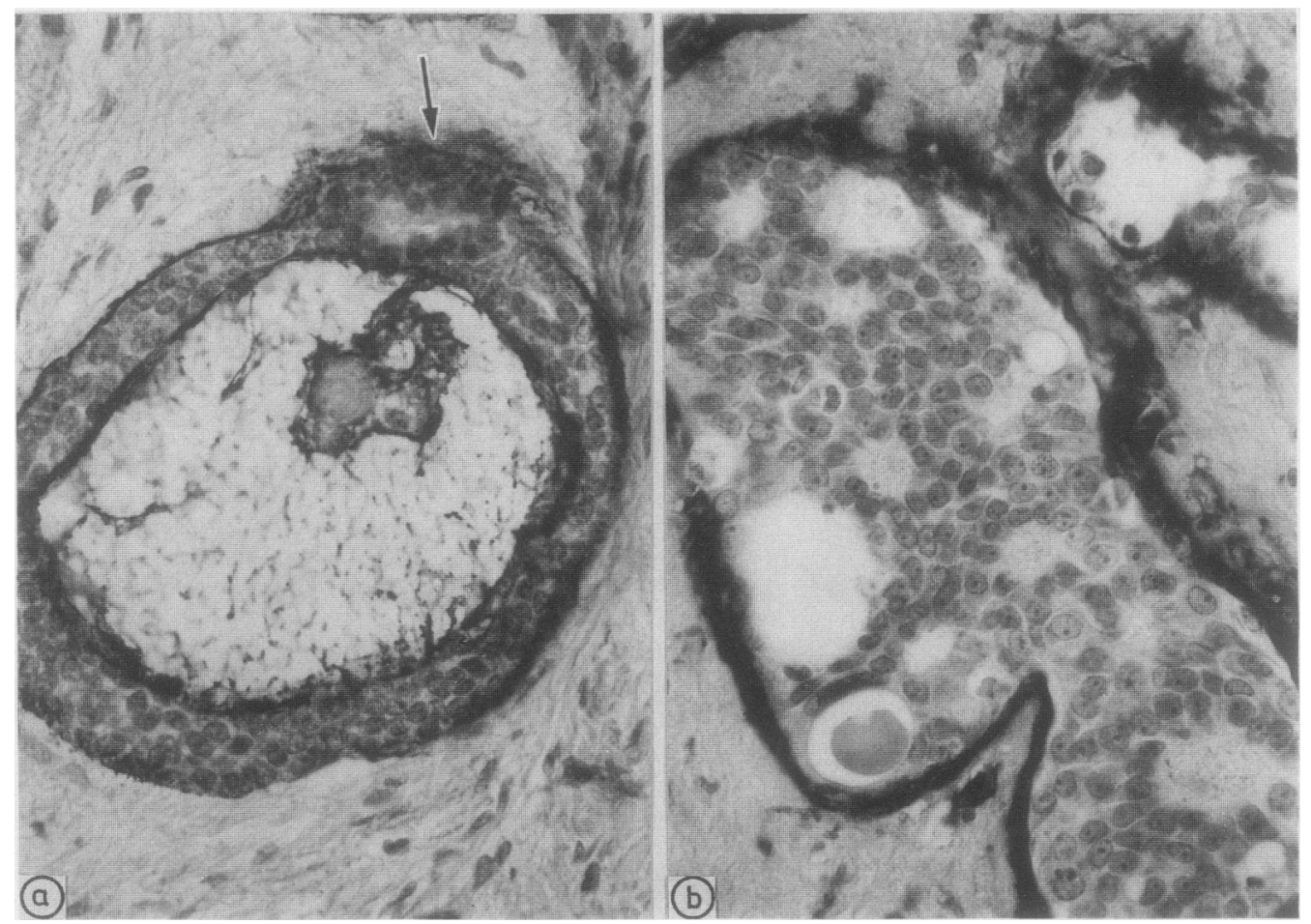

Fig 2 (a) Type IV collagen lines not only the outer margin of the tumour in the adenoid cystic carcinoma of the breast, but also the margin of the pseudocystic spaces. The spaces surrounded by ductular-like epithelia (arrow) are not lined by type IV collagen (CIV 22). (b) The tumour manifestations of the ductular carcinoma are also lined by basal lamina, but the cribriform lumina are negative for type IV collagen. (CIV 22.) 
lamina surrounded the intraductal and some of the larger invasive tumours at the centre as well as at the border of the carcinomas. Basal lamina were not detected at invasive tumour sites with strong tumour cell differentiation. In contrast to adenoid cystic carcinoma, no corresponding reaction product was seen to line the luminal cells as part of a cribriform growth pattern (fig $2 \mathrm{~b}$ ). Instead, the tumour cells secreted EMA, resulting in a positive staining reaction within the tumour cells, which comprised the cribriform pattern, and this was also seen within the spaces themselves (fig $3 \mathrm{~b}$ ). Vimentin was not expressed in tumour cells (fig 4b). The average fraction of positively staining cells was $72 \%$ for oestrogen receptors, $55 \%$ for progesterone receptors, and $18 \%$ for proliferative activity. One case was negative for both steroid receptors.

The data on the staining of the steroid receptors with $\mathrm{Ki}-67$ for ductal carcinomas are summarised in table 1 . The results for both tumour types are shown in table 2 .

\section{Discussion}

Adenoid cystic carcinoma of the breast is rare. ${ }^{26102930}$ According to Azzopardi, ${ }^{2}$ it comprises less than $1 \%$ of all breast carcinomas. Although comprising only minor parts of the tumour, the presence of numerous ductular formations allowed this tumour type to be identified easily in our case. This corroborates the statement that most adenoid cystic carcinomas of the breast can be diagnosed by routine light microscopic examination. ${ }^{1229}$

Adenoid cystic carcinoma may be confused, however, with ductal carcinoma with a cribriform growth pattern. This resulted in the rejection of some cases suggestive of adenoid cystic carcinomas of the breast. ${ }^{2}$ Further investigations are obviously necessary in difficult cases. If immunohistological analysis could help in differential diagnosis this would be more suitable than the use of electron microscopy, suggested by Harris in $1977 .{ }^{31}$

Adenoid cystic carcinomas have been identified

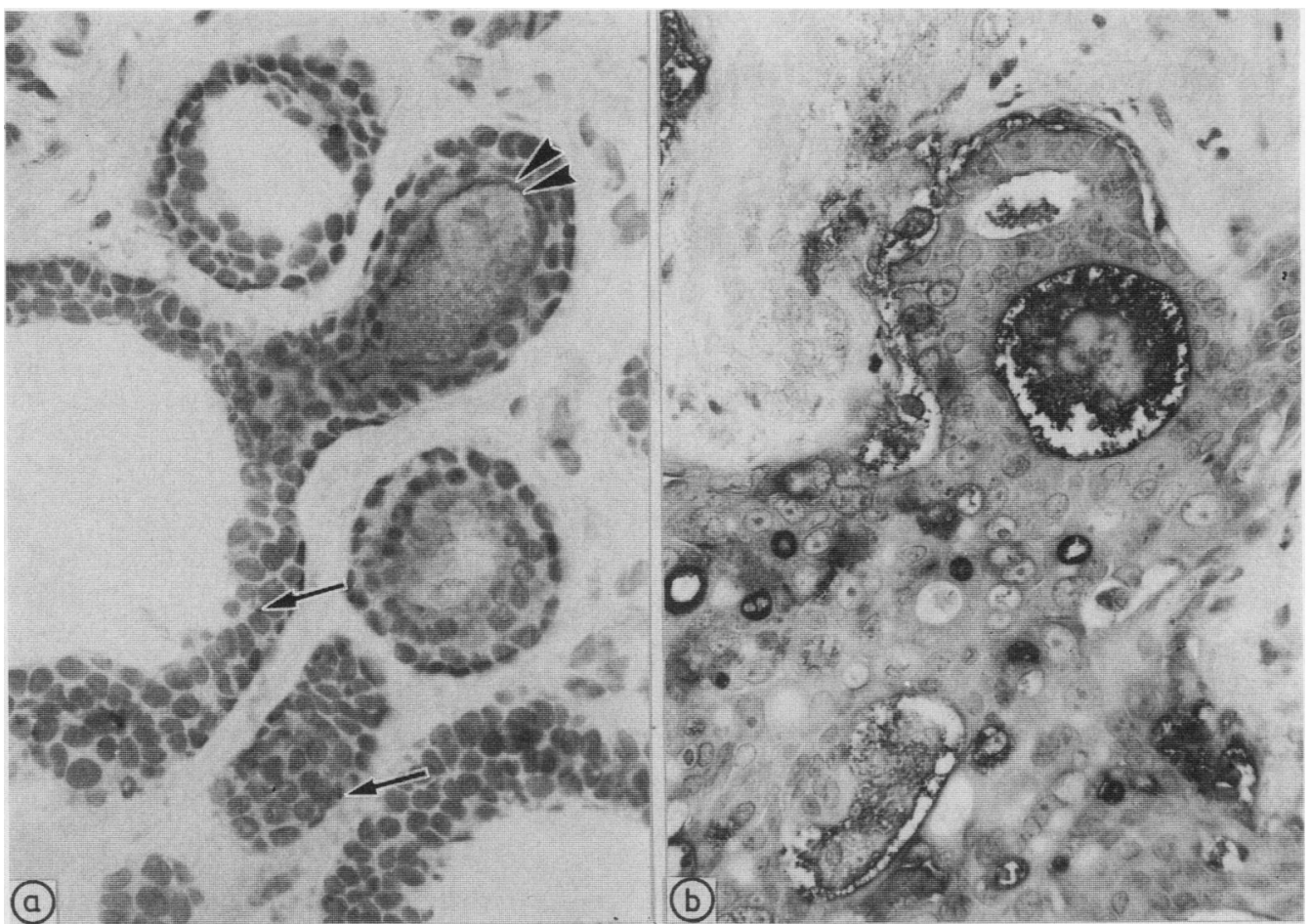

Fig 3 (a) The pseudocystic spaces of the adenoid cystic carcinoma are negative for EMA. Only a minority of myoepithelium-like cells shows a dot-like expression of EMA (arrows). The ductular spaces are lined by an EMAsecreting epithelium (arrowheads) (E29.) (b) The luminal border or tumour cells in ductular carcinoma with a cribriform growth pattern as well as the content of the cribriform spaces themselves react strongly with the EMA antibody. (E29.) 
Table 1 Proliferative activity and steroid hormone receptors in grade II ductal carcinomas with cribriform growth pattern

\begin{tabular}{llll}
\hline & $\begin{array}{l}\text { Growth } \\
\text { fraction }\end{array}$ & $\begin{array}{l}\text { Oestrogen } \\
\text { receptor }\end{array}$ & $\begin{array}{l}\text { Progesterone } \\
\text { receptor }\end{array}$ \\
\hline $\begin{array}{l}\text { Total number of cases } \\
\text { Number of negative }\end{array}$ & 7 & 7 & 7 \\
$\begin{array}{c}\text { cases } \\
\text { Percentage of positive } \\
\text { cells (average, range) }\end{array}$ & $18(5-35)$ & $72(70-95)$ & $55(25-90)$ \\
\hline
\end{tabular}

morphologically at different anatomical sites. ${ }^{3}$ In conjunction with the ultrastructural demonstration of basal lamina lining the pseudocysts, ${ }^{37-16}$ immunohistological methods in the breast ${ }^{713}$ and in salivary glands ${ }^{78}$ have shown these to be continuously surrounded by the basement membrane proteins laminin and fibronectin. The distribution of type IV collagen as a further component of the basement membrane was expected to show the same result. To our knowledge, however, this has not been shown to date. Thus, our results obtained with antibodies against type IV collagen expand the range of antibodies suitable for differential diagnosis of adenoid cystic carcinoma and
Table 2 Antigen expression in adenoid cystic carcinomas and ductal carcinoma with cribriform growth pattern

\begin{tabular}{|c|c|c|c|}
\hline & \multicolumn{2}{|c|}{ Adenoid cystic carcinoma } & \multirow[b]{2}{*}{$\begin{array}{l}\text { Ductal } \\
\text { carcinoma }\end{array}$} \\
\hline & $\begin{array}{l}\text { Myoepithelium- } \\
\text { like cells }\end{array}$ & $\begin{array}{l}\text { Ductular } \\
\text { epithelium- } \\
\text { like cells }\end{array}$ & \\
\hline $\begin{array}{l}\text { Type IV collagen } \\
\text { Vimentin } \\
\text { EMA } \\
\text { Oestrogen receptor } \\
\text { Progesterone }\end{array}$ & $\begin{array}{l}\text { Positive } \\
\text { Positive } \\
\text { Negative* } \\
\text { Negative }\end{array}$ & $\begin{array}{l}\text { Negative } \\
\text { Negative } \\
\text { Positive } \\
\text { Negative }\end{array}$ & $\begin{array}{l}\text { Negative } \\
\text { Negative } \\
\text { Positive } \\
\text { Positive† }\end{array}$ \\
\hline receptor & Negative & Negative & Positive $†$ \\
\hline
\end{tabular}

*Dot-like reactivity in a minority of cells. Pseudocysts always negative.

+One negative case

ductal carcinoma of the breast, and they further substantiate the basement membrane production of those tumour cells lining the pseudocysts. The immunostaining of their content is explained by the presence of basal lamina material in these "spaces"." In contrast to ductal breast carcinomas, the lining of the outer margin of infiltrating tumour cell complexes was always present in the adenoid cystic carcinomas.

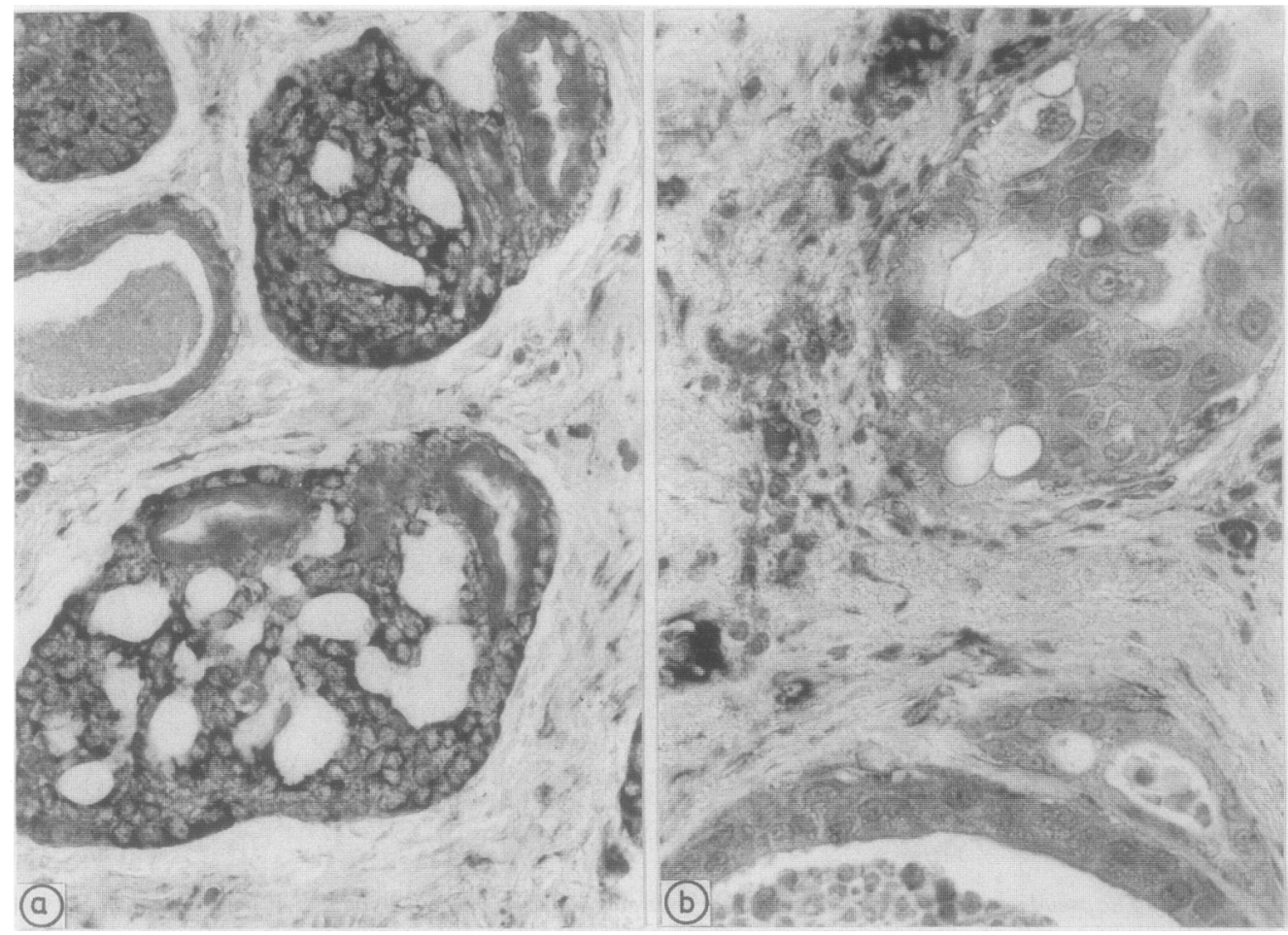

Fig 4 (a) The myoepithelium-like cells of the adenoid cystic carcinoma of the breast express vimentin unlike the ductular-like cells. (V9.) (b) The tumour cells of ductular carcinoma of the breast are negative for vimentin. The endothelium of blood vessels serves as an internal control. (V9). 
From these data, and the detection of EMA in normal breast epithelium and in malignant breast tissue, ${ }^{2532}$ it was concluded that the staining for EMA would show an inverse distribution. EMA had been detected in five of 37 adenoid cystic carcinomas of the breast by Sumpio et al, ${ }^{30}$ but they did not specify to which tumour component this referred. According to our results, immunostaining for EMA is suitable for the identification of adenoid cystic carcinomas of the breast, because the pseudocysts do not react while the epithelium lining the cribriform spaces of ductal carcinomas shows a distinct reaction, particularly at their luminal border. The spaces themselves are filled with immunostained material. The ductular spaces within the adenoid cystic carcinomas are also lined by cells positive for EMA, which lends further support to the hypothesis that there are two distinct cell types in this tumour.

Although the origin of adenoid cystic carcinoma is disputed, ${ }^{1015}$ that there is a myoepithelium-like differentiation of those tumour cells which line the pseudocystic spaces is widely accepted. ${ }^{1233} 34$ Correspondingly, the presence of actinomyosin has been shown within these cells by immunohistological methods. ${ }^{29}$ Because the myoepithelium of normal breast tissue stained positive for vimentin in our hands, our data on adenoid cystic carcinomas provide further evidence for the phenotypic similarity of both cell populations. This, however, does not mean that the tumour cells are derived from the myoepithelium. The presence of two epithelial tumour components favours instead the hypothesis that the tumour is derived from a highly potent precursor cell. ${ }^{12}$

Steroid hormone receptors were not detected in any of the adenoid cystic carcinomas. In contrast, six of our seven ductal carcinomas stained positively with most tumour cells reacting for both receptors (table 2). This corresponds with those data obtained on ductal carcinomas for both immunohistological ${ }^{35}$ and biochemical methods, ${ }^{3637}$ and it coincides with biochemical data for five cases of previously published cases of adenoid cystic carcinomas of the breast. ${ }^{112}$ Furthermore, it explains the negative result of antioestrogenic treatment in one case of adenoid cystic carcinoma of the breast. ${ }^{13}$ Only one case has been reported to be positive for oestrogen receptors by the dextran-coated charcoal method ${ }^{36}$ but determination of the biochemical receptors excludes detailed information about the tissue components. This result could thus be due to pre-existing, receptor positive residual cells of breast tissue, which may be interspersed as seen in our case. Immunohistological determination of hormone receptors is therefore preferable to biochemical assay.

Finally, the adenoid cystic carcinoma of the breast reported here showed low proliferative activity with the antibody $\mathrm{Ki}-67$. This parallels the observation of low mitotic counts in this tumour. ${ }^{12}$ Unfortunately, snap frozen material was not available in any case of adenoid cystic carcinoma of the salivary glands. Because adenoid cystic carcinomas at both sites share a prolonged clinical course, ${ }^{14630}$ differences in prognosis ${ }^{48}$ may be due to local conditions for detectability and radical surgery ${ }^{4}$ rather than to proliferating activity alone. Because growth in breast carcinomas depends on the grade of differentiation ${ }^{39}{ }^{40}$ grade II ductal carcinomas were taken for comparison in this study, although two different classification systems were applied. Our results for the grade II ductal breast carcinomas with cribriform growth patterns show a somewhat larger growth fraction than has been previously reported by Pickartz et al ${ }^{39}$ for unspecified invasive breast carcinomas with intermediate differentiation, but they are nearly identical with those reported by Barnard et al, as estimated from their fig $3 .^{40}$ The proliferative activity in breast carcinomas shown by $\mathrm{Ki}-67$ has also been determined by Gerdes $e t$ $a l^{41}$ but neither an average growth fraction nor a specification referring to the tumour grade was reported. The relatively high growth activity may partly explain the poorer prognosis of ductal carcinomas compared with adenoid cystic carcinomas of the breast. ${ }^{5}$ More data, however, are necessary to draw definite conclusions in this respect.

We thank Mrs H Steeger, I Winter, K Stamatoukou, M Thiel, A Schellmann and Mr D Born and L Oehring for their excellent technical assistance.

\section{References}

1 Thackray AC, Lucas RB. Tumors of the major salivary glands. Atlas of tumor pathology. Second series, Fascicle 10. Washington, DC: Armed Forces Institute of Pathology, 1974.

2 Azzopardi JG. Problems in breast pathology. Philadelphia: W B Saunders, 1979.

3 Lawrence JB, Mazur MT. Adenoid cystic carcinoma: a comparative pathologic study of tumors in salivary gland, breast, lung, and cervix. Hum Pathol 1982;13:916-24.

4 Cavanzo MFJ, Taylor HB. Adenoid cystic carcinoma of the breast. Cancer 1969;24:740-5.

5 Friedman BA, Oberman HA. Adenoid cystic carcinoma of the breast. Am J Clin Pathol 1970;54:1-14.

6 Peters GN, Wolff M. Adenoid cystic carcinoma of the breast: report of 11 new cases: review of the literature and discussion of biological behavior. Cancer 1979;52:1752-60.

7 D'Ardenne AJ, Kirkpatrick P, Wells CA, Davies JD. Laminin and fibronectin in adenoid cystic carcinoma. J Clin Pathol 1986;39:138-44.

8 D'Ardenne AJ, Burns J, Sykes BC, Bennett MK. Fibronectin and type III collagen in epithelial neoplasms of gastrointestinal tract and salivary gland. J Clin Pathol 1983;36:756-63.

9 Tandler B. Ultrastructure of adenoid cystic carcinoma of salivary gland origin. Lab Invest 1971;24:504-12. 
carcinoma of the breast. Arch Pathol Lab Med 1977;101:302-6.

11 Ro JY, Silva EG, Gallager HS. Adenoid cystic carcinoma of the breast. Hum Pathol 1987;18:1276-81.

12 Zaloudek C, Oertel YC, Orenstein JM. Adenoid cystic carcinoma of the breast. Am J Clin Pathol 1984;81:297-307.

13 Wells CA, Nicoll S, Ferguson DJP. Adenoid cystic carcinoma of the breast: a case with axillary lymph node metastasis. Histopathol 1986;10:415-24.

14 Orenstein JM, Dardick I, Van Nostrand AWP. Ultrastructural similarities of adenoid cystic carcinoma and pleomorphic adenoma. Histopathol 1985;9:623-38.

15 Koss LG, Brannan CD, Ashikari R. Histologic and ultrastructural features of adenoid cystic carcinoma of the breast. Cancer 1970;26:1271-9.

16 Tavassoli FA, Norris HJ. Mammary adenoid cystic carcinoma with sebaceous differentiation. Arch Pathol Lab Med 1986; 110:1045-53.

17 Gerdes J, Lemke H, Baisch H, Wacker H-H, Schwab U, Stein H. Cell cycle analysis of a cell proliferation-associated human nuclear antigen defined by the monoclonal antibody $\mathrm{Ki}-67 . J$ Immunol 1984:133:1710-15.

18 Szanto PA, Luna MA, Tortoledo ME, White RA. Histologic grading of adenoid cystic carcinoma of the salivary glands. Cancer 1984;54:1062-9.

19 Bloom HJG, Richardson WW. Histological grading and prognosis in breast cancer. Br J Cancer 1957;11:359-77.

20 Cordell JL, Falini B, Erber WN, et al. Immunoenzymatic labelling of monoclonal antibodies using immune complexes of alkaline phosphatase and monoclonal antialkaline phosphatase (APAAP) complexes. J Histochem Cytochem 1984;32:219-29.

21 Stein H, Gatter K, Asbahr H. Mason DY. Use of freeze-dried paraffin-embedded sections for immunohistologic staining with monoclonal antibodies. Lab Invest 1985;52:676-83.

22 Schuppan D, Besser M, Schwarting R, Hahn EG Radioimmunoassay for the carboxy-terminal cross-linking domain of type IV (basement membrane) procollagen in body fluids. J Clin Invest 1986;78:241-8.

23 Odermatt BF, Lang AB, Rüttner JR, Winterhalter KH, Trüeb B Monoclonal antibodies to human type IV collagen: useful reagents to demonstrate the heterodimeric nature of the molecule. Proc Natl Acad Sci USA 1984;81:7343-7.

24 Osborn M, Debus E, Weber K. Monoclonal antibodies specific for vimentin. Eur J Cell Biol 1984:34:137-43.

25 Cordell J, Richardson TC, Pulford KAF, et al. Production of monoclonal antibodies against human epithelial membrane antigen for use in diagnostic immunohistochemistry. $\mathrm{Br} J$ Cancer 1985;52:347-54.

26 Greene CL, Nolan C, Engler JP, Jensen EV. Monoclonal antibodies to human estrogen receptor. Proc Natl Acad Sci USA 1980;77:5115-19.

27 Perrot-Applanat M, Logeat F, Groyer-Picard MT, Milgrom E. Immunocytochemical study of mammalian progesterone receptor using monoclonal antibodies. Endocrinol 1985;116:1473-84.
28 Düe W, Pickartz H. Immunohistologic determination of the estrogen and progesterone receptors in disseminated peritoneal leiomyomatosis. Int J Gynecol Pathol 1988;(in press).

29 Anthony PP, James PD. Adenoid cystic carcinoma of the breast: prevalence, diagnostic criteria, and histogenesis. J Clin Patho 1975;28:647-55.

30 Sumpio BE, Jennings TA, Sullivan PD, Merino MJ. Adenoid cystic carcinoma of the breast. Ann Surg 1987;205:295-301.

31 Harris M. Pseudoadenoid cystic carcinoma of the breast. Arch Pathol Lab Med 1977;101:307-9.

32 Ceriani RL. Thompson K, Peterson JA, Abraham S. Surface differentiation antigens of human mammary epithelial cells carried on the human milk fat globule. Proc Natl Acad Sci USA 1977;74:582-6.

33 Gusterson BA, Warburton MJ, Mitchell D. Ellison M. Neville AM, Philip S. Distribution of myoepithelial cells and basement membrane proteins in the normal breast and in benign and malignant breast diseases. Cancer Res 1982;42:4763-70.

34 Gould VE, Miller J, Jao W. Ultrastructure of medullary, intraduc tal, tubular, and adenocystic breast carcinomas: comparative patterns of myoepithelial differentiation and basal lamina deposition. Am J Pathol 1975;78:401-16.

35 Reiner A, Reiner G, Spona J, Schemper M, Kolb R, JakeszHolzner JH. Vergleich von immunhistochemischem Östrogenrezeptornachweis beim Mammakarzinom und Beziehungen zur histologischen Tumorklassifikation. Verh Dtsch Ges Pathol 1986:70:243-6.

36 Kern WH. Morphologic and clinical aspects of estrogen receptors in carcinoma of the breast. Surg Gynecol Obstet 1979;148:240-2.

37 Alanko A, Markinen J, Scheinin TM. Tolppanen E-M, Vihko R Correlation of estrogen and progesterone receptors and histological grade in human primary breast cancer. Acta Pathol Microbiol Immunol ( Sect A) 1984;92:311-5.

38 Galloway JR, Woolner LB, Clagett OT. Adenoid cystic carcinoma of the breast. Surg Gynecol Obstet 1966;135:1289-94.

39 Pickartz H, Gerdes J, Schwarting R, Stein H. Zur Bedeutung des lympho-phagozytären Infiltrates von Mammakarzinomen für die lymphonoduläre Metastasierung. Verh Dtsch Ges Pathol 1985:69:269-73.

40 Barnard NJ, Hall PA, Lemoine NR. Kadar N. Proliferative index in breast carcinoma determined in situ by $\mathrm{Ki} 67$ immunostaining and its relationship to clinical and pathological variables. $J$ Pathol 1987:152:287-95.

41 Gerdes J, Pickartz H, Brotherton J, Hammerstein J, Weitzel H, Stein $\mathrm{H}$. Growth fractions and estrogen receptors in human breast cancers as determined in situ with monoclonal antibodies. Am J Pathol 1987:129:486-92.

Requests for reprints to: Dr W Düe, Institut für Pathologie, Klinikum Steglitz der Freien Universität Berlin, Hindenburgdamm 30, D-1000 Berlin 45, West Germany. 